\title{
An Analysis of Self-Talk and Flow State of Athletes in Team and Individual Sports
}

\author{
Mehmet Emre Eryucel ${ }^{1}$ \\ ${ }^{1}$ Akdeniz University Faculty of Sport Sciences, Turkey \\ Correspondence: Mehmet Emre Eryucel, Faculty of Sport Sciences, Akdeniz University, Turkey. E-mail: \\ eeryucel@akdeniz.edu.tr
}

Received: February 26, 2019

Accepted: March 22, 2019 Online Published: March 26, 2019

doi:10.5539/jel.v8n2p286

URL: https://doi.org/10.5539/jel.v8n2p286

\begin{abstract}
The purpose of this study is to analyze the self-talk and optimal emotional state of athletes in team and individual sports. In this research, 86 females and 156 males - a total of 242-athletes participated on a voluntary basis. The self-talk scale and the optimal performance emotion state scale were identified as data collection tools in the scope of the research. For the analysis and evaluation of the data, descriptive statistical methods and Independent Sample t-test were used. The analyses were carried out using the SPSS package, and the significance level was determined as $\mathrm{P}<0.05$. Upon evaluation of the findings in terms of branch and gender variables, no significant difference was observed in the optimal performance emotion states and self-talk levels of the athletes who took part in the study. It can be concluded that individual or team sports do not have an influence on self-talk or optimal performance emotion state of athletes.
\end{abstract}

Keywords: self-talk, flow state, sport

\section{Introduction}

With the increase in sports awareness and the efforts to improve performances in sports, the correlation between sports and psychology is also increasing each day. The psychological states of athletes, their sports and social lives, and their interaction has been a topic of interest (Yarayan, Yıldız, \& Gülşen, 2018; Yıldız, Şenel, \& Şahan, 2015; Eroğlu, Yıldırım, \& Şahan, 2017).

Self-Talk, as a psychological skill in sports literature, has been a hot topic among researchers in recent years (Theodorakis, Weinberg, Natsis, Douma, \& Kazakas, 2000; Landin \& Hebert, 1999; Bayköse, Civar Yavuz, Çoban, Şahan \& Certel, 2016; Bayköse, 2018; Gülşen, Yıldız, Bayköse, \& Eryücel, 2018; Nergiz, Bayköse \& Yıldız, 2015; Şahin, Bayköse, \& Civar Yavuz, 2017b; Bayköse, Civar Yavuz, Özer, \& Şahin, 2017; Şahin, Bayköse, \& Civar Yavuz, 2017a; Karaca, Şahin, Şahin, \& Bayköse, 2018).

Scientists have been attempting to answer the questions related to the understanding of psychological events and phenomena in the fields of sports and exercise, and discovering their relationship with performance (Harvey, Van Raalte, \& Brewer, 2002; Theodorakis, Weinberg, Natsis, Douma, \& Kazakas, 2000; Johnson, Hrycaiko, Johnson, \& Hallas, 2004; Perkos, Theodorakis, \& Chroni, 2002; Landin \& Hebert, 1999; Hamilton, Scott, \& McDougall, 2007).

Self-talk can be described as the verbal expression of athletes which serves instructional and motivational purposes, related to multidimensional sports. Although positive self-talk is approved by athletes and coaches, little is known about this mental skill (Hardy \& Hall, 2005). Studies show that planned self-talk enables improvement in the acquisition of skills and performance in sports (Neck \& Manz, 1992). Studies also reveal the existence of various types of self-talk, and that these can be effective in different performances in sports (sensitivity or power) (Vealey, 2007). Self-talk must be positive and its nature sensible. Athletes must use self-talk to reconstruct their cognitive states and to metamorphose irrational thoughts that cannot adapt to the environment. Other uses are self-rewarding (Hardy \& colleagues, 2007) and increasing effort (In: Bayköse, 2014). Self-talk, as explained in the field, has two functions, namely instructive and motivational; along with two aspects, namely positive and negative (Hardy, 2006). Self-talk proved to be an effective strategy in improving performance (Hardy, 2006). It is believed that the analysis of the functions of self-talk will enrich our understanding of the underlying mechanisms behind it and allow the development and application of 
comprehensive programs of psychological skill training. It is of utmost priority that, regarding the flow state, the psychological factors that help athletes achieve in today's sports and exercise driven activities. In order to understand the psychological processes that could contribute to the performance quality, studying the mental structures related to optimal performance has been another topic of interest to researchers (Bayköse, 2014).

The flow state that reflects psychological and mental state occuring through optimal performance experience during physical activity is another subject of study for the researchers in the field. The flow state (flow) is defined as the optimal mental state that occurs when the perceived challenges and skills are balanced during a physical activity (Csikszentmihalyi, 1990). The flow state is a state of highly focused concentration. It refers to an absolutely focused involvement in an activity. Theoretically, it is expected that flow state, as an optimal mental state, be related to the optimal sports performance in addition to its contribution to an optimal experience. Flow state is generally regarded as a peak state in performance (Jackson, Thomas, Marsh, \& Smethurst 2001).

In the light of the above, the current study aims to analyze self-talk and flow state of athletes in team and individual sports.

\section{Method}

\subsection{Research Group}

In order to achieve the goal of this research, 86 women, 156 men (242 athletes in total) voluntarily participated in the study. The participants' demographical distribution showed that $35 \%$ of the participants were women; while $65 \%$ of them were men. The percentage of the participants' sport branches is as follow: $50 \%$ were team and $50 \%$ were individual branches.

\subsection{Data Collection Tools}

In accordance with the aim of the study, a Self-Talk Questionnaire (STQ), Flow state Scale (OPSS) and a Personal Information Form, which was designed by the researcher according to the goals of the research, were chosen as the data collection tools in the current study.

\subsection{Self-Talk Questionnaire}

The Self-Talk Questionnaire (STQ, Appendix 1) was designed by Zervas, Stavrou and Psychountaki (2007) in order to reveal the individual differences that were identified in relation to the motivational and cognitive processes in self-talk (Zervas et al., 2007). The Turkish culture adaptation was carried out by Engür (2011), where the Cronbach alpha value was .93 in the "motivational function" subscale. In the "cognitive function" subscale, the Cronbach alpha value, which is the internal consistency coefficient, was 0.87 . The general reliability coefficient of the scale was identified as 0.95 (Engür, 2011).

\subsection{Flow State Scale}

Developed by Jackson and Eklund, the purpose of the Flow State scales (Flow State and Dispositional Flow Scales) is to evaluate the flow state during physical activity and sports. The Turkish culture adaptation of the scale was applied by Aşçı et al. (2007). As regards its reliability coefficients, Cronbach alpha internal consistency coefficients ranged from 0.42 (Specific Feedback, Control Feeling) to 0.87 (Decrease in Self-Awareness, Aşçı et al., 2007).

\subsection{Personal Information Form}

Prepared and designed by the researcher to serve the purpose of the current study, the personal information form aims to elicit such demographic pieces of information as the athlete's gender, age, his/her sports branch, as well as whether s/he is a national athlete or not, experience in years, and practice frequency in the sport branch.

\subsection{Analysis of the Data}

For the evaluation of the data, descriptive statistical methods and Independent Sample t-test were used. The analyses were carried out using the SPSS package, and the significance level was determined as $\mathrm{P}<0.05$. As the data is normally distributed, the study followed a parametric test manner.

\section{Results}

Table 1. T-test table of athletes' flow state regarding the branch variable

\begin{tabular}{lllllll}
\hline & Branch & $\mathrm{n}$ & mean & S.D. & $\mathrm{t}$ & $\mathrm{p}$ \\
\hline \multirow{2}{*}{ Flow state } & Individual & 121 & 3.6508 & .59255 & -0.432 & 0.666 \\
& Team & 121 & 3.6839 & .59855 & & \\
\hline
\end{tabular}


When Table 1 was analyzed in terms of the branch variable, there was no significant difference in the flow state point averages of the participants who took part in the study as athletes who play individual or team sports.

Table 2. T-test table of athletes' flow state regarding the gender variable

\begin{tabular}{lllllll}
\hline & Gender & $\mathrm{n}$ & mean & S.D. & $\mathrm{t}$ & $\mathrm{p}$ \\
\hline Flow state & Female & 86 & 3.6160 & .58741 & -0.999 & 0.319 \\
& Male & 156 & 3.6957 & .59844 & & \\
\hline
\end{tabular}

When Table 2 was analyzed in terms of the gender variable, no significant difference was found in the flow state point averages of the participants who took part in the study as athletes playing individual or team sports.

Table 3. T-test table of athletes' self-talk levels regarding the branch variable

\begin{tabular}{lllllll}
\hline & Branch & $\mathrm{n}$ & mean & S.D. & $\mathrm{t}$ & $\mathrm{p}$ \\
\hline Cognitive Process & Individual & 121 & 3.6576 & .86828 & 0.686 & 0.494 \\
& Team & 121 & 3.5750 & 1.00229 & & \\
Motivational Function & Individual & 121 & 3.7107 & .97948 & -0.493 & 0.623 \\
& Team & 121 & 3.7727 & .97681 & & \\
\hline
\end{tabular}

When Table 3 was analyzed in terms of the branch variable, no significant difference was detected in the self-talk level point averages of the participants who took part in the study as athletes who play individual or team sports.

Table 4. T-test table of athletes' self-talk levels regarding the gender variable

\begin{tabular}{lllllll}
\hline & Gender & $\mathrm{n}$ & mean & S.D. & $\mathrm{t}$ & $\mathrm{p}$ \\
\hline Cognitive Process & Female & 86 & 3.6811 & .92001 & 0.798 & 0.426 \\
& Male & 156 & 3.5806 & .94673 & & \\
Motivational Function & Female & 86 & 3.8634 & .95921 & \multirow{2}{*}{1.442} & 0.151 \\
& Male & 156 & 3.6747 & .98268 & & \\
\hline
\end{tabular}

Upon the analysis of Table 4 in terms of the gender variable, no significant difference was found in the self-talk level point averages of the participants who took part in the study as athletes who play individual or team sports.

\section{Discussion and Conclusion}

Upon the analysis of the collected data, with respect to the branch variable, there was no statistically significant difference between athletes' flow state and their self-talk levels.

As far as the related literature is concerned, however, Yildiz et al. (2015) observed significant differences in favor of male athletes' flow states in terms of the gender variable, which supports the findings obtained in the current study.

In other studies by Bayköse (2014), Jackson et al. (2001), Koehn (2007), Russell (2001) and Erkmen, Zengin and Aşçı (2010), no significant difference was found in the flow state with respect to gender. The findings of these studies support our current research, and the results are consistent with our findings in general. Nevertheless, upon research on the lower dimensions of flow state, which are namely task difficulty - skill balance, specific feedback, achievement experience, action-awareness combination, clear targets, task focus, control emotion and time transformation, certain statistical differences were reported, as well as analyses on lower dimension general in addition to flow state (Çetinkalp, 2011; Ersöz, 2011).

Similar results were obtained in terms of the branch variable. Studies by Jackson et al. (2001), Koehn (2007), Russell (2001) reveal results consistent with our findings, although contradicting results can also be seen when compared to other studies (Çetinkalp, 2011; Ersöz, 2011).

The related literature on self-talk in athletes includes several studies on the realities of athletes' speaking with each other as a result of differences observed in favor of male or female athletes (Gammage et al., 2001). However, the findings do not support the findings of our study. In terms of branch, on the other hand, researchers' findings demonstrate consistency with our study (Katsikas et al., 2009). 
In conclusion, both topics of our research are subjects of intensive research by scholars in our country and around the world. As previously mentioned, it will be too hasty to put forward precise comments based on the current study. Though the issue has been investigated by several studies (Hardy, Gammage, \& Hall, 2001; Hatzigeorgiadis, Zourbanos, Galanis, \& Theodorakis, 2011; Van Raalte, Vincent, \& Brewer, 2016) our research sheds light on the fact that individual or team sports do not have an influence on self-talk or optimal performance emotion state of athletes. It is believed that a great deal of research is needed within our country in order to demonstrate whether optimal levels of performance and self-talk can be altered in terms of demographic characteristics.

\section{References}

Aşçı, F. H., Çağlar, E., Eklund, R. C., Altıntaş, A., \& Jackson, S. (2007). Durumluk ve Sürekli Optimal Performans Duygu Durum-2 Ölçeklerinin Uyarlama Çalışması. Hacettepe Journal of Sport Sciences, 18(4), 182-196.

Bayköse, N. (2014). Sporcularda Kendinle Konuşma ve Imgeleme Düzeyinin Optimal Performans Duygu Durumunu Belirleyici Rolü. Selçuk Üniversitesi. Sağlık bilimleri Enstitüsü. Beden Eğitimi ve Spor Anabilim Dalı. (Yayımlanmamış) Yüksek Lisans Tezi, Konya.

Bayköse, N. (2018). Kendinle Konuşma Ölçeği’nin (KKÖ) Beden Eğitimi Dersi İçin Geçerlilik ve Güvenilirliği. Kilis 7 Aralık Üniversitesi Beden Eğitimi ve Spor Bilimleri Dergisi, 2(1), 8-16.

Bayköse, N., Civar Yavuz, S., Özer, Ö., \& Şahin, A. (2017). The role of self-talk and self-efficacy levels of athletes studying at faculties of sport sciences on predicting mental toughness. Turkish Online Journal of Educational Technology, December Special Issue, 591-595.

Bayköse, N., Civar Yavuz, S., Çoban, M., Şahan, H., \& Certel, Z. (2016). Role of self talk in prediction of passion level in physical education class environment. Turkish Online Journal of Educational Technology, 2016, 445-452.

Carter, L. (2013). Running in the Zone: Mental Toughness, Imagery, and Flow in First Time Marathon Runner. Unpublished PhD Thesis, Department of Kinesiology, Temple University in Philadelphia.

Csikszentmihalyi, M. (1990). Flow. In M. Csikszentmihalyi (Ed.), The Psychology of Optimal Experience (1st ed., p. 281). Newyork: Harper Perennial Pub.

Engür, M. (2011). Performans Başarısızlığı Değerlendirme Envanteri ve Kendinle Konuşma Anketinin Türk Sporcu Popülasyonu'na Uyarlanması ve Uygulanması. Ege Üniversitesi, Sağllk Bilimleri Enstitüsü. Sporda Psikososyal Alanlar Anabilim Dalı. Doktora Tezi, İzmir.

Eroğlu, O., Yıldırım, Y., \& Şahan, H. (2017). Spor Bilimleri Fakültesindeki Öğrencilerin Akademik Öz-Yeterlik ve Akademik Güdülenme Düzeyleri Arasındaki İlişkinin İncelenmesi: Akdeniz Üniversitesi Örneği. Türkiye Spor Bilimleri Dergisi, 1(1), 38-47.

Ersöz, G. (2011). Egzersize Katılım Güdüsü, Sürekli Optimal Performans Duygu Durumu Ve Sosyal Fizik Kaygı Düzeyinin Egzersiz Davranış Basamağına ve Fiziksel Aktivite Düzeyine Göre Irdelenmesi. Doktora Tezi. Ege Üniversitesi, Sağlık Bilimleri Enstitüsü, Sporda Psiko Sosyal Alanlar Ana Bilim Dalı. İzmir.

Gülşen, D. B. A., Yıldız, A. B., Bayköse, N., \& Eryücel, E. (2018). Bireysel ve Takım Sporu Yapan Spor Bilimleri Fakültesi Öğrencilerinin Kendinle Konuşma Düzeylerinin Çeşitli Değişkenlere Göre İncelenmesii. Akdeniz Spor Bilimleri Dergisi, 1(2), 58-66.

Hamilton, R. A., Scott, D., \& MacDougall, M. P. (2007). Assessing the effectiveness of self-talk interventions on endurance performance. Journal of Applied Sport Psychology, 19(2), 226-239. https://doi.org/10.1080/10413200701230613

Hardy, J., \& Hall, C. R. (2005), A Comparison of Test-Retest Reliabilities Using the Self-Talk Use Questionnaire. Journal of Sport Behavior, 28(3), 201-215.

Hardy, J. (2006). Speaking Clearly: A Critical Review of the Self-Talk Literature. Psychology of Sport and Exercise, 7, 81-97. https://doi.org/10.1016/j.psychsport.2005.04.002

Hardy, J., Gammage, K., \& Hall, C. (2001). A descriptive study of athlete self-talk. The Sport Psychologist, 15(3), 306-318. https://doi.org/10.1123/tsp.15.3.306

Hardy, L., Jones, G., \& Gould, D. (2007). Understanding Psychological Preparation for Sport (p. 42). Chichester, England: John Wiley \& Sons Ltd. 
Harvey, D. T., Van Raalte, J. L., \& Brewer, B. W. (2002). Relationship between self-talk and golf performance. International Sports Journal, 6(1), 84-91.

Hatzigeorgiadis, A., Zourbanos, N., Galanis, E., \& Theodorakis, Y. (2011). Self-talk and sports performance: A meta-analysis. Perspectives on Psychological Science, 6(4), 348-356. https://doi.org/10.1177/1745691611413136

Jackson, S. A., \& Eklund, R. C. (2004). The Flow Scales Manual. Morgantown, WV: Fitness Information Technology, Inc.

Jackson, S. A., Thomas, P. R., Marsh, H. W., \& Smethurst, C. S. (2001). Relationships between Flow, Self-Concept, Psychological Skills, and Performance. Journal of Applied Sport Psychology, 13, 129-153. https://doi.org/10.1080/104132001753149865

Johnson, J. J. M., Hrycaiko, D. W., Johnson, G. V., \& Hallas, J. M. (2004). Self-talk and female youth soccer performance. The Sport Psychologist, 18, 44-59. https://doi.org/10.1123/tsp.18.1.44

Karaca, A. A., Şahin, F., Şahin, A., \& Bayköse, N. (2018). Motivational Self-Talk and Mental Toughness Relationship in Athletes: Mediator Role of Friend Support. The Turkish Online Journal of Educational Technology, November Special Issue (2), 181-186.

Kelecek, S. (2013). Sporcuların Tutkunluk Düzeylerinin; Optimal Performans Duygu Durumu, Güdüsel Yönelim ve Hedef Yönelimini Belirlemedeki Rolü. Yüksek Lisans Tezi. Başkent Üniversitesi, Sağlık Bilimleri Enstitüsü. Egzersiz ve Sportif Performans Anabilim Dalı. Ankara.

Landin, D., \& Hebert, E. P. (1999). The İnfluence of Self-Talk on the Performance of Skilled Female Tennis Players. Journal of Applied Sport Psychology, 11, 263-282. https://doi.org/10.1080/10413209908404204

Neck, C. P., \& Manz, C. C. (1992). Thought Self-Leadership: The Influence of Self-Talk and Mental Imagery on Performance. Journal of Organizational Behavior, 13(7), 681-699. https://doi.org/10.1002/job.4030130705

Nergiz, S., Bayköse, N., \& Yıldız, M. (2015). Kendinle Konuşma: Modern ve Halk Dansları Yapan Bireylerin Kendileriyle Konuşma Durumları. Niğde Üniversitesi Beden Eğitimi ve Spor Bilimleri Dergisi. Cilt 9, Özel Sayı.

Perkos, S., Theodorakis, Y., \& Chroni, S. (2002). Enhancing performance and skill acquisition in novice basketball players with instructional self-talk. Sport Psychologist, 16(4), 368-383. https://doi.org/10.1123/tsp.16.4.368

Şahin, A. (2017). Grekoromen Ve Serbest Stil Güreş Yapan Sporcuların Kendileriyle Konuşma Düzeylerinin İncelenmesi. Kilis 7 Aralı Üniversitesi Beden Eğitimi ve Spor Bilimleri Dergisi, 1(1), 60-64.

Şahin, A., Bayköse, N., \& Civar Yavuz, S. (2017a). Does the undergraduate athletes ${ }^{\text {ee }}$ self talk levels affect imagery levels? Turkish Online Journal of Educational Technology, December Special Issue, 867-871.

Şahin, A., Bayköse, N., \& Civar Yavuz, S. (2017b). The role of motivational self-talk and life satisfaction on determining the flow experience of undergraduate athletes. Turkish Online Journal of Educational Technology, December Special Issue, 867-871.

Theodorakis, Y., Weinberg, R., Natsis, P., Douma, I., \& Kazakas, P. (2000). The effects of motivational versus instructional self-talk on improving motor performance. Sport Psychologist, 14(3), 253-271. https://doi.org/10.1123/tsp.14.3.253

Van Raalte, J. L., Vincent, A., \& Brewer, B. W. (2016). Self-talk: Review and sport-specific model. Psychology of Sport and Exercise, 22, 139-148. https://doi.org/10.1016/j.psychsport.2015.08.004

Vealey, R. S. (2007). Understanding and Enhancing Self Confidence İn Athletes. In G. E. Tenenbaum (Ed.), Handbook of Sport Psychology (3rd ed., p. 298). Hoboken, New Jersey: John Wiley \& Sons, Inc.

Yıldız, A. B., Gülşen, D. B. A., \& Yılmaz, B. (2015). Sporcuların Optimal Performans Duygu Durumunun Yaşam Tatminleri Üzerindeki Etkisi. Beden Eğitimi ve Spor Bilimleri Dergisi, 9.

Yıldız, M., Şenel, E., \& Şahan, H. (2015). The relationship between prosocial and antisocial behaviors in sport, general self-efficacy and academic self-efficacy: Study in department of physical education and sport teacher education. Journal of Human Sciences, 12(2), 1273-1278. https://doi.org/10.14687/ijhs.v12i2.3202

Zervas, Y., Stavrou N., \& Psychountaki, M. (2007). Development and Validation of the Self-Talk Questionnaire

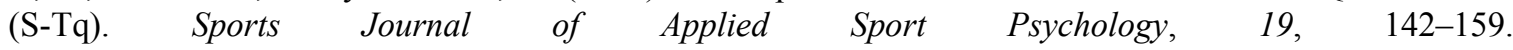
https://doi.org/10.1080/10413200601185156 


\section{Copyrights}

Copyright for this article is retained by the author, with first publication rights granted to the journal.

This is an open-access article distributed under the terms and conditions of the Creative Commons Attribution license (http://creativecommons.org/licenses/by/4.0/). 